AperTO - Archivio Istituzionale Open Access dell'Università di Torino

\title{
Equity crowdfunding in Technology Transfer Strategies and Licensing
}

\section{This is the author's manuscript}

Original Citation:

Availability:

This version is available http://hdl.handle.net/2318/1664227

since 2018-03-28T15:18:28Z

Terms of use:

Open Access

Anyone can freely access the full text of works made available as "Open Access". Works made available under a Creative Commons license can be used according to the terms and conditions of said license. Use of all other works requires consent of the right holder (author or publisher) if not exempted from copyright protection by the applicable law. 


\title{
Equity crowdfunding in Technology Transfer Strategies and Licensing
}

\author{
Luca Dezi \\ Department of Management and Quantitative Studies, \\ University of Naples "Parthenope" \\ Via Generale Parisi, 13 - Palazzo Pacanowski 80132, Naples, Italy \\ Email:luca.dezi@uniparthenope.it \\ Valentina Cillo \\ Link Campus University \\ Via del Casale San Pio V, 44, 00165, Rome, Italy \\ Email: v.cillo@unilink.it \\ *Corresponding author \\ Antonio Usai \\ Department of Economics and Business \\ University of Sassari \\ Via Muroni, 25, 07100, Sassari (Italy) \\ Email: ausai@uniss.it \\ Paola Pisano \\ Department of Informatics \\ University of Turin \\ Via Pessinetto, 12, 10149, Torino, Italy \\ Email: paola.pisano@unito.it
}

\begin{abstract}
The main aim of this study is to investigate to what extent equity crowdfunding could enable firms to outsource research and development activities. Likewise, the present study aims at analyzing the relationship between desorptive capacity and equity crowdfunding performance. We also aim at studying the mediation role of ICT firms capabilities, connective capacity and minor equity ownership. In this regard, this study intends to pioneer into connecting the knowledge management theory with the crowdfunding studies. A sample of 180 projects based on the top ten European equity crowdfunding platforms has been used. Findings indicate that desorptive capacity enables companies in developing external knowledge retention and expoitation wich in turn enhance equity crowdfunding performance.
\end{abstract}

Keywords: Crowdfunding; Technology transfer; Licensing; External knowledge management; Desorptive capacity; Connective capacity; ICT capabilities; Equity ownership

\section{Biographical notes:}


Luca Dezi is Full Professor of Economics and Business Management at the University "Parthenope", Faculty of Economics, Naples. Furthermore, he is Professor of Strategic Marketing and International Business at the Faculty of Communication Sciences, Department CO.RI.S. University of Studies of Rome, Sapienza. Member of the Company's Board of Auditors San Giovanni Addolorata Hospital in Rome from 2007 to 2011. - Ordinary member of the Italian Academy of Business Economics - Chartered accountant and Auditor. He is a consultant in the field of economic and financial analysis, planning and management control, evaluation of businesses and projects, corporate restructuring, mediations, rationalization and resource management, teaching and training on behalf of medium-sized and large companies, public institutions and organizations.

Valentina Cillo holds a Doctoral degree from University of Sannio (Italy). She graduated from Faculty of Communication Sciences, Department CO.RI.S., University of Studies of Rome Sapienza and consecutively worked as a consultant with different industries. Her main research interests concern innovation management, knowledge transfer and corporate social responsibility. He has substantial experience in working with industry-related projects funded by private and public research programmes

Antonio Usai is senior researcher of Economics and Business Management, Professor of Strategic Marketing for Tourism and Digital Marketing and Revenue Management at the Department of Economics and Business of the University of Sassari. His major interests include tourism product development and tourism marketing, analysis of domestic and international tourist demand (with particular reference to China), customer satisfaction and consumer behaviour in tourist systems, innovation management and knowledge management, international marketing for SMEs.

Paola Pisano is researcher of innovation and business model in Computer science Department University of Torino. She is the director of smart factory laboratory of the ICXT, the interdepartmental and multidisciplinary centre of innovation and the deputy Mayor in charge of innovation and Smart city for Torino (Italy). Concerning teaching activities, she is professor of Innovation in Computer science department (University of Torino). She is the Author of more than 70 publications in relevant and international journals. 


\section{Introduction}

The process through which an organization is affected within knowledge and technology transfer processes by the experience of another one, requests special attention as widely adviced into the leading managerial literature (Argote and Ingram 2000; Malik, 2004; Meissner and Carayannis, 2017).

Due to the competitive dynamics, knowledge had been widely recognized as a fundamental asset for organizations (Teece, 2007; Secundo, Magnier-Watanabe, Heisig, 2015). Actually, knowledge transfer has become one of the most critical knowledge management processes inside contemporary worldwide enterprises (Kuhn and Abecker 1997; Bollinger and Smith, 2001; Albino et. al. 2007; Krylova, Vera, Crossan, 2016).

Companies are increasingly showing interest in Research \& Development (R\&D) outsourcing and external cooperation. Nevertheless, some barriers yet occur, especially when considering the small businesses. Indeed, R \& D activities generally have high degree of uncertainty. Main reasons are the information asymmetry between the partners and the high costs of knowledge transfer. This can partly be explained by the existence of risk-averse and short-term financial markets as widely highlited (Veugelers and Cassiman 2005, Del Giudice et al., 2016).

For these reasons, recently empirical research has recognized the crucial role of the on line digital platforms for knowledge transfer purposes and R\&D outsourcing processes (Brown and Harris, 2010; Aloini, Farina, Lazzarotti, Pellegrini, 2017; Randhawa, Josserand, Schweitzer, Logue, 2017).

In this regard, four categories of digital platforms had been mainly identified: Club of experts, Crowdsourcing, Coalitions, Communities of related spirits (Plant, 2004; Fronteer Strategy, 2009; Roser et al., 2014). The basic rules and requirements for participation, the type of governance and the rules of engagement define the platform category.

Due to the growing practicioners' interest in R\&D activities outsourcing, crowdsourcing merits special attention.

Crowdsourcing is based on the principle that for every challenge, there is a person able to contribute in terms of innovative ideas. The number of contributors involved rather than their experience gives back the main aspect for the effectiveness of the initiative. The function of the contributors, in this case, is to support the initiator in the exploration of new innovative ideas and in a better understanding of the needs of their stakeholders. The crowd can also invest in entrepreneurial ideas and projects that had been initiated by entrepreneurs which turn to non-traditional financing methods, in order to obtain the necessary financial resources for implementing their ideas.

This emerging approach to fundraising via the Internet had been defined "crowdfunding" (Belleflamme and Lambert, 2014) as it represents a novel mechanism to cope the resource constraints as well as to improve interorganizational relationships. As leading management scholars highlighted, since crowdfunding is based on digital platforms embedded in the current financial innovation (Moenninghoff 
and Wieandt, 2013; Belleflamme and Lambert, 2014; Ahlers, Cumming, Guenther, Schweizer, 2015), it produces convergent innovation (Dubé et al., 2014). It means that crowdfunding is an innovation likely to produce both economic and social (human) outcomes.

Starting from this scenario, the main aim of this study is to contribute to the research in this field by investigating to which extent equity crowdfunding could enable firms to outsource research and development activities. Likewise, the present study aims at analyzing the relationship between desorptive capacity, as the ability to identify technology transfer opportunities and to transfer technology to the recipients (Dell'Anno, Del Giudice, 2015), and equity crowdfunding perfomance.

As knowledge management theory suggests, digital platforms can increase the exchange of resources and the sharing of knowledge through desorption (DCAP) (Korbi, Chouki, 2017). For this reason, this dimension had been widely employed in the literature on open innovation (Nahapiet and Ghoshal, 1998; Mollick, 2013; Natalicchio et al., 2017). Starting from this theoretical background, this study develops a theoretical model aimed at analyzing and managing the effects of this strategic dimension of knowledge management on equity crowdfunding performance. More specifically, this research widens the previous literature on the effects of crowdfunding platforms basically in two ways (Mollick, 2014; Agrawal, Catalini, Goldfarb, 2011). Firstly, the current literature is mainly exploratory and adopts research methods like the case studies (Ordanini, Miceli, Pizzetti, 2011; Mollick, 2014;). In this regard, this study intends to pioneer into connecting the knowledge management theory with the crowdfunding studies. Secondly, this study contributes to the main literature on acquisitions of company shares, by identifying a relationship between minority equity acquisition and innovation.

To test our theoretical arguments, we utilized data collected from a dataset of over 180 projects based on the top ten European equity crowdfunding platforms. The measure employed to select the 10 best platforms is the capital raised from their first campaign.

This paper is organized as follows. We first provid a literature review of the current research on the links between the equity crowdfunding studies and the knowledge management theory. Then, we define the research design and the research hypotheses. Next, we presente and discuss an empirical test. Finally, we discuss the main findings and draw some implications for research and practice, limitations of the present study and conclusive remarks.

\section{Theoretical background}

\subsection{Equity crowdfunding}


Today Web 2.0 technologies are enabling companies to outsource their internal business activities by assigning them to individuals or to the crowd on the Internet (Howe, 2006; Edvardsson and Durst, 2014). These entrepreneurs can obtain financial resources from the crowd in various open social communities. This emerging approach of raising money via the Internet is called crowdfunding. A clear definition of the term has not yet been proposed. The best known description was elaborated by Hemer (2011). He defines crowdfunding as a mechanism for financial resources procurement through online platform. Schwienbacher (2014) offer a similar definition.

In recent years, managerial research community has particularly analyzed crowdfunding from three main perspectives. First, some studies investigated the conditions that encourage entrepreneurs to adopt crowdfunding rather than other fundraising approaches (Schwienbacher and Larralde, 2010; Belleflamme and Lambert, 2014). According to Schwienbacher and Larralde (2010), entrepreneurs of these projects are well informed and skilled with Web 2.0 technologies. They are also willing to expand their skills sets. Secondly, some studies analyzed motivations of entrepreneurs and sponsors in crowdfunding (Belleflamme, Lambert, Schwienbacher, 2010; Gerber, Hui, Kuo, 2012). According to the authors, the main motivations to start crowdfunding projects are how to raise money, how to attract the public and how to get feedback from the crowd for the offered products and services. Thirdly, some scholars studied determinants of crowdfunding performance (Cordova, 2015). Furthermore, few studies analyzed the role of crowdfunding in the research transfer mechanisms (Gajda and Mason, 2013; Belleflamme \& Lambert, 2014; Hornuf and Schwienbacher, 2014).

From this categorization, we could identify four main types of crowdfunding: donation-based, rewardbased, lending, and equity, based on what investors receive for their contributions (Schwienbacher and Larralde, 2010; Giudici et al., 2012; Belleflamme and Lambert, 2014).

In the present study, we just focused on equity crowdfunding as a model in which funders receive an interest in the form of equity or equity-like arrangements (Bradford, 2012). We believe that equity crowdfunding is the most relevant context for empirically understanding how to empower firms to outsource research and development activities (Edvardsson \& Durst, 2014). In crowdfunding platforms, generally the risk of ongoing research is not completely transferred to the focal firm. In fact, the use of a third-party innovator like crowdfunding platforms ensures that the focal firm has no R\&D structure to reassign or liquidate in case of failure (Gajda and Mason, 2013; Belleflamme and Lambert, 2014; Hornuf and Schwienbacher, 2014).

Moreover, according to Hagedoorn (2002; 2003), in recent years the weaker ties of contractual arrangements are more attractive than locking up assets in a joint venture. This change reflects greater complexity of scientific and technological development, greater uncertainty around R\&D, increased costs of $R \& D$ projects and shorter innovation cycles that foster collaboration. This dynamic is considered 
particularly strong in high-tech industries due to the importance of flexibility in the fastest-changing technology sectors.

Despite of this, some barriers could affect effectiveness of knowledge transfer mediated by crowdfunding. As several scholars highlight, $\mathrm{R} \& \mathrm{D}$ collaboration between firms is typically viewed as a pooling of competencies through a contract-based arrangement (such as licensing, joint development, etc.) or a pooling of resources through joint ownership and control of a special purpose structure (Hagendoorn, 2012). From a competencies perspective, companies generally prefer to collaborate with people with demonstrable communication and collaboration skills (Kleyn, 2010). According to a capability-based view of open innovation processes, this means that connective capacity, known as the process stages of maintaining knowledge in interorganizational relationships and subsequently reactivating this knowledge, represent a strategic factor (Garud and Nayyar, 1994; Zollo and Winter, 2002; Chesbrough, 2003; Grant and Baden-Fuller, 2004; Argote et al., 2000; 2003; Khedhaouria and Jamal, 2015). Digitalism is a transversal gap; then, a decisive step in this direction can only begin to argue in the light of the ecosystem for firms, universities and institutions and civil society to join forces and travel united (Carayannis and Campbell, 2012; Aloini, Farina, Lazzarotti, Pellegrini, 2017).

In order to better understanding the role of knowledge management in equity crowdfunding, this study analyzes the mediation role of minory equity acquisitions in enhancing licensing mechanism, investement risk decreas and formal collaboration improvement. As also Chesbrough highlighted (2002), the objective of a corporate venture capital (CVC) can be either financial or strategic. The financial objective is to generate a return through an increase in the value of the equity investment.

Hence, by focusing on equity crowdfunding, we shouldn't consider a minority stake as an alternative to a full acquisition because focal firms has already determined that access to a technology or product and not internalization of the investee's resources is their current goal.

\subsection{External Knowledge management perspective}

External knowledge management is a multidimensional construct. Several researchers attempted to define its dimensions in many ways through an integrative perspective of firm boundaries (Santos and Eisenhardt, 2005; Jacobides and Billinger, 2006; Chesbrough, 2006; West, 2014; Shin, Han, Marhold, Kang, 2017). They considered exploration, retention and exploitation of knowledge inside and outside the organization's boundaries. These dynamics describe the "skills of knowledge" as a firm's ability to manage different knowledge processes. To explore, retain and exploit external knowledge, three capacities of knowledge are needed: absorption, connectivity and desorption (Argote et al., 2000; Lane et al., 2006; Fosfuri, 2008; Mortara et al.,, 2011; Cruz-González, López-Sáez, Navas-López, Delgado- 
Verde, 2014; Dell'Anno and Del Giudice, 2015; Ferraris, Santoro and Dezi, 2017). Despite of this, earlier open innovation research focused more on inbound processes (Mortara and Minshall, 2011, Edvardsson and Durst, 2014).

This study aims at highlighting the gap whereby, despite the importance of external knowledge exploitation and retention for firms across different industries, it has remained underdeveloped (Shin et al. 2017).

Considering main concerns about declining number of licenses, recently, the term desorptive capacity (DCAP) appeared more frequently in current discussions. Scholars considered it as a facilitator of knowledge transfer (Le Masson et al., 2012; Dell'Anno and Del Giudice, 2015). From this point of view, the declining number of licenses indicates a declining license effectiveness. The main reasons for explaining this negative trend are: a) Complexity in lincenses negotiation; b) Licenseability/commercial viability; c) Expertise in effectively "package" and "market" the type of deal that is needed for the innovation to be commercialized; d) New licensing models.

These elements represent the fundamental base of connective capacity known as the firm's ability to retain knowledge in interfirm relationship; it comprises elements of alliance and relational capability (Kale and Singh, 2007; Schreiner, Kale and Corsten, 2009; Schilke and Goerzen, 2010).

Connective capacity is closeley related to absorpite capacity. Actually, the more a company has a certain knowledge in a particular field, the easier it is to manage interfirm relationships and to profit from external knowledge retention. Accordingly, connective capacity comprises the process stages of maintaining knowledge in interorganizational relationships and subsequently reactivating this knowledge (Garud and Nayyar, 1994; Grant and Baden-Fuller, 2004; Dell'Anno and Del Giudice, 2015).

The lack of these capacities could better explain why companies perform more inbound than outbound activities (Chesbrough and Crowther, 2006).

\section{Research design}

\subsection{Desorptive capacity}

Companies are increasingly resorting to external knowledge exploitation, even though they often face considerable difficulties in external commercialization management (Lichtenthaler, 2009).

In line with Lichtenthaler (2009), we considered external exploitation of knowledge based on commercialization of knowledge assets. For a successful outward technology transfer, a sufficient ability to exploit externally knowledge, called desorptive capacity, is needed (Lichtenthaler, 2009).

Starting from this scenario, we decided to focus our research just on the external knowledge exploitation and on retention capacities (Chirico and Salvato, 2008; Andreeva and Kianto, 2012). 
According to recent research in external knowledge capacity (Papa et al., 2018), we belive that external knowledge exploitation could affect equity crowdfunding performance throughout technology orientation, connectivity capacity and partial equity ownership. Hence, we mainly hypotesize the following:

Hp1: Desorptive capacities positively affect equity crowdfunding performance.

The contest of our research is based on equity crowdfunding platforms.

Through merging research into knowledge management and dynamic capabilities, we thus developed an integrative perspective focused on external knowledge retention and exploitation. We identified the following two 'knowledge capacities' as a firm's strategic capabilities of externally managing knowledge in outbound open innovation processes: connective and desorptive capacity (Chesbrough and Crowther, 2006; Le Masson et al., 2012).

We considered crowdfunding performance as dependent variable. One dimension of external knowledge exploitation, desorptive capacity, is identified as antecedent factor. We used ICT capabilities, connectivity capacity and equity ownership as mediators into the developed model. Moreover, we included the goal of a crowdfunding project and the duration of the project as control variables (Fig. 1).

-FIGURE 1 AROUND HERE

\subsection{Equity acquisition}

Since university research represents the basis of spinouts, these companies are required to negotiate a licensing agreement with the university's technology transfer office (TTO). While licensing, the TTO aims to retain some of the value of technology for the university. The economic terms of the license agreement generally includes royalty fee and equity stakes. Generally, equity can based on money or on the skills brought to the company (Castro Casal and Neira Fontela, 2007; Wang et al., 2017). For this reason, many universities are approaching equity crowdfunding platforms. Many crowdfunding platforms launched by USA Universities emerged and, recently, such initiatives started in Europe as well. Academic Crowdfunding has been proved as a useful tool to manage the lack of private funding sources as well as to support research transfer activities in their different forms (Benner and Sandstrom, 2000; wright et al., 2006; Munari and Toschi, 2011; 2015; Edvardsson and Durst, 2014). Hence, similary to corporate venture capital (CVC), the objectives of equity crowdfunding investor can be either financial or strategic (Chesbrough, 2003; Wheat et al., 2013; Marlett, 2015).

Investing in innovative companies through equity crowdfunding, companies obtain the position of shareholders and, consequently, the right to the division of profits. Furthermore, several studies showed that crowdfunding contributes to the exploration of knowledge (Belleflamme and Lambert, 2014; Hornuf 
and Schwienbacher, 2014). Despite of this, no study has yet focused on the link between equity crowdfunding and expoitive capacity by investing companies. This means that the effect of minor equity acquisition on the desorptive capacity of the investing companies is still unknown.

Thus, we hypothesize that:

Hp2: Equity acquisition mediates the relationship between desorptive capacity and equity crowdfunding performance

\subsection{ICT capabilities}

ICT capabilities could affect crowdfunding performances (Cruz-González et al. 2014). For instance, crowdfunding emphasizes the digital divide (socio-economic and / or age-based) as crowdfunding primarily attracts a certain type of entrepreneur: Young and Social Network literate (Gelfond and Foti, 2012; Aloini et al., 2017).

For this reason, we would better understand the role of ICT firms capabilities, particurly analyzing if the additional barriers in licensing may be mitigated by ICTs (Mata et al., 1995; Ray et al., 2004; Del Giudice and Straub, 2011).

Dynamic Capability Perspective (DCP) offers an analysis of ICTs where competitive advantage captures the ability to use ICT by allowing companies to adapt more quickly to external environment. This guarantees a Sustained Competitive Advantage (SCA) (Teece et al., 1998; 2007). Stressing the impact of ICT on competitive advantage, Pavlou and Sawy (2006) found that this relationship was mediated by organisational dynamic capability resources, such as coordination capacity, absorption capacity, collective orientation and market orientation. As a matter of fact, these organisational resources can be improved by digital options (Pavlou and Sawy, 2006)

Even if the link between ICT and knowledge management is evident (Porter and Millar, 1998; Melville et al., 2004; 2007), few studies explore the required resources, capabilities and competences to enable ICT in organisational dynamic capabilities and firm competitiveness.

However, through business processes and digital knowledge systems, digital options enable a company's infrastructure to initiate various and frequent competitive actions (Sambamurthy et al., 2003; Piccoli and Ives, 2005; Chi and Holsapple, 2005; Overby et al., 2006; Aloini et al., 2017).

Thus, we hypothesize that:

Hp3: ICT capabilities mediates the relationship between desorptive capacity and equity crowdfunding performance

\subsection{Connective capacity}

Crowdfunding has been assessed as a useful tool to connect entrepreneurs, researchers and potential lenders who can provide financial capital (Wheat et al., 2013; Marlett, 2015). It has also been highlighted 
that these intermediation platforms act as marketplaces that can also reduce the weight of geographical proximity in the innovation process (Agrawal et al., 2011).

Despite the advantages, adopting open innovation throughout crowdfunding platforms is a challenging process (Chesbrough et al., 2006). Collaborating with a number of partners is more complex because of increased coordination and control efforts. Several studies demonstrated that many firms do not feel comfortable in some 'open' scenarios in which the return especially depends on the partnering actors. As a matter of fact, networks of innovating partners bring with them significant strategic and organizational challenges, about which there is little prior knowledge (Surowiecki, 2005; Vanhaverbeke et al., 2006; 2008; Tapscott and Williams, 2007; Korbi and Chouki, 2017).

According to the leading knowledge management literature, the competence needed to connect and stay connected with partners has been generally introduced as connective capacity. Lichtenthaler (2009) described connective capacity as the firm's ability to maintain knowledge in inter-firm relationships. This enables firms' collaborations and knowledge transfer (Korbi and Chouki, 2017; Randhawa et al., 2017). In digital platforms, the ability of maintaining knowledge in interorganizational relationships and subsequently reactivating this knowledge is a critical factor (Garud and Nayyar, 1994; Grant and BadenFuller, 2004; Pandza and Holt, 2007; Aloini et al. , 2017). Combining external retention and external expoitation firms could improve information transfer from informal networks, R\&D collaboration, and technology acquisition (Shin et al., 2017)).

Thus, we hypothesize that:

Hp4: Connective capacity mediates the relationship between desorptive capacity and equity crowdfunding performance

\section{Methods and materials}

Starting from the previously analyzed theoretical framework, this study involves the elaboration of a conceptual model to conduct the empirical research following two main steps. First, the literature review led us to identify the variables and the measures and then to develop the questionnaire. Second, we tested the model and hypotheses through SPSS Statistics 24.0 software. We employed a regression model, considered as a suitable method in innovation management studies (Kutner, Nachtsheim and Neter, 2004).

To ensure the generalization of results, we based our research on a survey methodology, considered useful for improving (Dooley, 2001). According to the relevant literature about validity measurements, all variables were developed using multi-item scales (Bergkvist and Rossiter, 2007; 2009).

The questions were based on the funnelling technique (Oppenheim, 1992) asking to respondents to 
evaluate several statements with a seven-point likert scale (Likert, 1932; Munshi, 2014). In order to avoid the risk of rationalizing the answers of the respondents, the single questions have been separated. Furthermore, we separated dependent and independent variables within the questionnaire to reduce potential common method variance (Podsakoff et al., 2012).

\subsection{Data Collection}

We collected data from a dataset of 250 projects based on the top ten european equity crowdfunding platforms by capital raised since their founding: Crowdcube (United Kingdom), FundedByMe (Sweden), Companisto (Germany), Invesdor (Finland), Seedmatch (Germany), Seeders (United Kingdom), Funderbeam (Estonia), MyMicroInvest (Belgium), WiSEED (France), Startupxplore (Spain).

We firstly analyzed Terms of Use Agreement of these ten platform specifically focusing on Intellectual Property Rights section. We found that they include the right to grant supplemental licenses to investors. Then, we selected projects including supplemental licenses rights. Moreover, in order to satisfy theoretical sampling conditions (Shadish et al., 2002), we considered just projects launched after the successful campaign is terminated, in order to determine the notion of "successful innovation".

The survey was administired to the founder entrepreneurs with equity position in selected projects. Specifically, we collected data from firms' investors.

A questionnaire, composed of 5 sections and 55 questions based on existing validated constructs was sent to 250 firms. In order to involve companies, an e-mail was sent them containing the questionnaire and an explanation of study's purpose. In total 180 firms expressed the interest in joining the study. Hence, the final sample size includes 180 cases for analysis. This satisfy sample size requirements in mediation models (Wolf et al. , 2013; Sideridis et al. , 2014; Muthén and Muthén, 2002).

\subsection{Measures}

All variables were measured using existing validated constructs. Since the items were placed on a sevenpoint Likert scale, a higher score on each scale mean a greater consonance with the question (Likert, 1932; Jamal, 2014). Variable measures were employed as follows.

Desorptive capacity. This capacity happens under two separate processes: first, in identifying technology transfer opportunities, and second, in transferring knowledge and facilitate the technology's application at the recipient (Lichtenthaler, 2009). Since desorptive capacity refers to what is necessary for external exploitation, it has been usually measured through the number of licenses (Blau, 2006; Kirschbaum, 2005). Accordingly, in order to capture the complete process of external knowledge expoitation as a 
dynamic capability, we utilized the scale by Blau (2006). The scale demonstrated acceptable reliability: Cronbach's $\alpha=0.74$.

Equity acquisition. We considered managers' subjective assessments origining in the management literature as an operationalisation of a multidimensional performance construct (Mahoney, 1967). Managers' subjective assessment allows us to capture the complex view of performance taking into account differing management objectives (Brouthers et al., 1998). We chose it because this is applicable across all types of acquisitions. Since managers' perceptions define their reality and influence their behaviour and attitudes (Krug and Hegarty, 2001), they can be used where objective measures are not available (Dess and Robinson, 1984). The questionnaire we employed based on measures Schoenberg (2006) adapted from Datta and Puia (1995). It comprised nine performance parameters: return on investment; return on sales; asset utilisation; earnings per share; share price; cash flow; tax efficiency; growth in sales revenues; purchase of undervalued assets. According to Schoenberg (2006), respondents of this study were asked to evaluate the importance of each performance criterion at the time of acquisition as well as the gap between acquisition's performance and their previous expectations. Hence, we obtained a "weighted performance" for each criterion. The scale showed high reliability (Cronbach's $\alpha=0.85$ ). In a separate question, respondents also provided their "overall" rating of the acquisition's performance. This score showed high consistency with their "overall" performance rating $(r=0.91 ; \mathrm{p}<0.001)$.

ICT capabilites. To measure this we considered digitised enterprise work processes and knowledge systems which allow to launch competitive actions (Sambamurthy et al., 2003). Following Tippins and Sohi (2003) we defined ICT capabilities as the way firms use technologies to effectively manage their information. We considered three different dimensions: IT knowledge, IT operations and IT infrastructure. These dimensions represent the organization's capacity to effectively manage the exchange of information with the competitive environment (Tippins and Sohi, 2003).

The ICT capabilities scale was adapted from Tippins and Sohi's (2003) and includes 11 items. Items about the firm's knowledge, skills and experience in the use of IT measure the IT knowledge. For the IT operations and IT infrastructure dimensions, the items measure the use of collaboration technologies, as well as the tools and systems available in the firm to acquire and store information that are useful indicators in the decision-making. Cronbach's $\alpha$ for this scale was equal 0.71 , thus expressing a high value of reliability.

Connective capacity. It was measured considering the ability of firms to retain knowledge within themselves. Three indicators were employed to measure it: estimation of the extent to which R\&D collaborations with various partners (e.g. suppliers or competitors) contribute to product innovation and its total effect; the expenditure for external R\&D activities, rescaled to six levels; and finally, the number of patent cross 
licensing. The scale demonstrated acceptable reliability: Cronbach's $\alpha=0.71$ for partners' contribution to product innovation, Cronbach's $\alpha=0.74$ for the expenditure for external R\&D activities.

Equity crowdfunding performance. It was captured through a multi-faceted four item subjective scale of Driv, Segev and Shenhar (1993) covering financial objectives, performance relative to customers, sales objectives and success in capturing new opportunities. Cronbach's $\alpha$ for this scale was equal 0.71, thus expressing acceptable value of reliability

Control variables. We also collected data for two controls with the specific aim to exclude the influence of two extraneous variables. Crowdfunding goal was measured through the total amount of money that an entrepreneur aimed to raise for a particular project. Moreover, the study analyzed the Crowdfunding duration measured through the number of days from the start to the end of a project (Bao and Huang, 2017).

Model fit. All analyzed constructs reported acceptable Cronbach's $\alpha$. A confirmatory factorial analysis through SEM was conducted in order to examinated the model fit indices: CMIN (chi-square value)/DF degrees of freedom $=1.82$; CFI $($ Comparative Fit Index $)=0.76$; RMSEA (Root Mean squared $)=0.05$. Since obtained degrees of freedom ratios range between 2 and 1, results suggest an acceptable fit between the hypothetical model and the sample data (Carmines \& McIver, 1981; Byrne, 1989).

Common method bias. As recent studies suggested, we tested for common method variance (CMV) through multiple tests (Podsakoff et al., 2012). We stressed the potential problem of common method bias, which describes the measurement error that is compounded by the sociability of respondents who want to provide positive answers (Chang et al., 2010). Since this paper studies collected data on both the independent and dependent variables from the same respondents at one point in time, common method variance as false internal consistency might be present in the data. Since no single factor emerged as dominant during exploratory factor analysis, common method bias was not a major concern.

\section{Findings}

As shown in Table 1, variables were log-transformed for data analysis. While model 1 includes just two control variables, model 2 also considers desorptive capacity dimension. Since the variance inflation factor (VIF) is less than 2, a low correlation of independent variable with independent variables was found. This means that there is no evidence of collinearity problems (Freund and Littell, 2000; Salmerón Gómez et al., 2016). This result confirms the significant effect of the desorptive capacity and crowdfunding performance $(\mathrm{b}=0.08, \mathrm{p}<0.001)$. Therefore, $\mathrm{H} 1$ was supported. 
According to Cohen (1983), descriptive statistics and correlation analysis were conducted to highlight potential relationships between variables (Table 2). Since none of the correlation shows more than acceptable limit of 0.5 , multicollinearity was not a concern. Moreover, complete correlation between variables was found. Therefore, we carried out mediation analysis in order to assess to what extent third variables affect the relation between independent and dependent variables (MacKinnon, 1999; 2000; Donaldson, 2001; Kraemer et al. 2002). We followed the causal steps approach outlined in the work of Kenny, Kashy, and Bolger (1998) in order to test the three mediations. We firstly tested the relationship between the independent variable (DCAP) and the mediating variables Equity ownership, ICT capabilities, Connective capacities and Equity crowdfunding performance (Andersom, Covin and Slevin, 2009).

TABLE 2 AROUND HERE

As results of the regression analysis shown (Table 3) a positive significant relationship between DCAP and the mediators exists (models 3, 4 and 6). Therefore, we proceeded to the next step in which the direct relationship between DCAP and equity crowdfunding performance was tested. Results are presented in Table 4, model 10 and 11. The results show a positive significant mediation. In fact, the mediators reported a a larger standardized coefficient than independent variable DCAP. Furthermore, the nonsignificance of the independent variable DCAP denotes full mediation. Thus, three of the four proposed hypotheses were accepted. This means that both the minor equity acquisition and the connective capacity are predictors of the equity crowdfunding performance.

\section{TABLE 3 AROUND HERE}

\section{Discussion}

Findings confirmed that desorptive capacity enables companies in developing external knowledge retention and expoitation, which in turn enhance equity crowdfunding performance.

After examined the main constructs through the most recent managerial literature review, this study explored the mediating mechanism in the relationship between DCAP and equity crowdfunding performance. Consistently with the theoretical background, this study confirms that DCAP, through its 
connection with minor equity ownership and external knowledge retention, is likely to improve crowdfunding performance.

Implication for theory. Combining the literature of crowdfunding with the knowledge management one, this study indicates that the desorptive capacity is a significant antecedent of equity crowdfunding performance (Hp 1). This finding confirms previous studies. Infact, through desorpive capacity one business could achieve major monetary and strategic benefits from transferring technology, including significant licensing revenues and learning effects (Chesbrough, 2006; Lichtenthaler, 2009). Through licensing, firms not only gains economic benefits but also non-monetary strategic advantages, such as access to external knowledge (Arora et al., 2001). Hence, we could consider our findings consistent with empirical studies about OI adoption modalities (Penin, 2011).

From this perspective, the rapid growth of the equity crowdfunding model is opening new opportunities. Specifically, our results reveal that retaining equity leads to the provision of details about risk, reducing asymmetric information. Furthermore, equity ownership can be interpreted as commitment and engagement signal. These two factors can positively influence the success of both funding and knowledge transfer processes. (Hp 2). Hence, according to Chesbrough (2006), we should consider equity crowdfunding investment as "enabling mechanism". This means that successful investment enables a company's own businesses to benefit without any operational link between innovators and the company (Chesbrough, 2006). Our results clearly show that under a regime of weak intellectual property protection (IPP), it is less likely to create an investment relationship between entrepreneurs and holdings. On the contrary, under a strong IPP regime, the chances of an investment relationship increase. Finally, our findings suggest that intellectual property rights can facilitate the knowledge and technology transfer. This confirms the leading literature on competitive advantage and knowledge outsourcing (Hagedoorn, 2002; 2003).

As several leading scholars highlighted, ICT capabilities could facilitate the process of knowledge transfer. Exploiting external knowledge through digital ecosystems, could facilitate the acquisition and management of knowledge (Del Giudice and Straub, 2011). This lead us to conclude that ICTs provide firms with a Sustained Competitive Advantage (SCA) (Teece et al., 1997; Pavlou and Sawy, 2006). However, findings did not support the mediation role ( $\mathrm{Hp} 3)$. This result can be explained by inferring a possible inverse causality of the relationship. Moreover, other contingent factors could arise. For example, the level of innovation of a country can affect the average level of digital literacy of citizens and businesses, especially in the case of small and medium-sized enterprises. Starting from this perspective, new digital platforms are basing their business on integrated knowledge-based value chain models. They offer to their customers a wide range of services: matching with new ventures, IP protection and commercializzation, financing and learning.

The fourth hypotesis of our study argues that firms engaged in equity crowdfunding platforms stand to 
benefit when they utilize their desorptive capacity to facilitate the improvement of connective capacity, wich in turn helps firm to retain knowledge within themselves (Hp4). This means that external exploitation could affect firms R\&D collaborations with various partners (e.g. suppliers or competitors), investment in external $\mathrm{R} \& \mathrm{D}$ activities and finally, the number of patent cross licensing. Equity crowdfunding websites provide the technical platforms for exchanging funds, voting rights, comments, and private messages. According to Schwienbacher and Larralde (2010), donation model provides passive investments with limited interactions and low commitment. Otherwise, active investments allow crowdfunding sponsors not only to invest but also to constantly interact with the entrepreneurs, through services and products feedback too (Schwienbacher and Larralde, 2010; Lehner and Kaniskas, 2012).

Mangerial implications. Our research highlights that while enterprises with less financial resources would prefer to invest on innovative projects, in order to access to strategic knowledge, on the contrary the equity crowdfunding is the most right choice for them. In fact, it allows to obtain both financial and strategic advantages with modest financial efforts, quite high rendiment and limited risk of failure. This means that crowdfunding platforms help firms to deal with main knowledge transfer problems and support the management of solutions.

After identifying opportunities for exploiting external knowledge on the basis of the above-mentioned monetary and strategic reasons (Chesbourgh, 2003), firms have to transfer knowledge to the recipient.

The relevance of desorption capacity is closely related to the ability of the company to exploit external knowledge, which is complementary to internal knowledge application in a firm's own product range (Lichtenthaler, 2009).

Through the licensing activity, firms could obtain economic benefits, but also non-monetary strategic advantages. The main advantages include access to external knowledge, the possibility of using industry standards and operating on cross-licensing agreements with others companies (Grindley and Teece, 1997; Arora et al., 2001; Cruz-González et al., 2014). However, the ability to maximize revenues of innovations is closely related to the appropriability conditions that depend on the availability and effectiveness of the formal and informal systems of protection from imitation. When the level of appropriability is low, like it happens in absence of patents, investments in external exploitation are to be preferred to investments in external exploration. The explanation for this may be that the results of investments in external exploitation (e.g. new products) could be more easily protected by available informal means. As Lavie et al. (2010, p. 120) write, "Under such conditions [of a weak appropriability regime], the value of exploration is diminished so that organizations may withhold their investment in exploration and focus on exploitation". 
Our findings also reveal that within innovation process, especially when the type of technological knowledge is based on multiple sources of knowledge (universities, research laboratories, companies), proximity based on digital platforms plays a critical role. This is also because the tacit nature of knowledge can inhibit the use of tools to transfer knowledge. At the same time, this means that face-to-face interaction allows potential applications of knowledge exchange.

This is the reason why it is reasonable to associate digital platforms with innovation ecosystems rather than with technological systems (Russell et al. 2016; Randhawa et al., 2017).

Limitation and future research. The results of this study highlight some limitations that should be taken into consideration. Firstly, since objective data are hardly available, data from this study have been collected from a single respondent and measured subjectively. This can generally generate common bias. Moreover, the subjective evaluation of managers can be subject to managerial prejudices (Bowman and Ambrosini, 1997). Moreover, results can be influenced by the interviewees' familiarity with the original objectives of the acquisition (Datta, 1991). To this aim, several rigorous tests to avoid common method error were conducted.

Secondly, longitudinal replication of this study is needed in order to obtain more robust findings (Ployhart et al., 2010).

The current research, therefore, offers several insights for further research in the areas of innovation management. First of all, it is not clear why some firms are able to reach a greater number of licensee contracts than others (Arora et al., 2001). Moreover, further analysis is needed to differentiate to what extent knowledge should be protected (Luoma et al., 2010).

Finally, it is necessary to further analyze the relationship between company size and external exploitation capacity. According to van de Vrande et al. (2006) open innovation practices are more accessible for larger companies than for smaller ones, as the former have more formalized R\&D and innovation procedures. As also Lavie et al. (2010, p.120) highlighted, “conflicting findings exist concerning the impact of organizational size on the tendency to explore versus exploit". More specifically, as size increases, firms tend to become less flexible and less adaptable to change, limiting knowledge exploration opportunities. On the other hand, larger organizations may have easier access to internal and external knowledge resources.

\section{Conclusive remarks}

Our findings reveal that crowdfunding contributes to the external exploration and retention of knowledge (Belleflamme and Lambert, 2014; Hornuf and Schwienbacher, 2014). This means that business could achieve major monetary and strategic benefits from transferring technology, including 
significant licensing revenues and learning effects (McConnachie, 1997; Patrick, 1999; Chesbrough, 2006; Lichtenthaler, 2009; Chou and Passerini, 2009). Intellectual property rights management can facilitate knowledge transfer (Chi and Holsapple, 2005; Chou and Passerini, 2009; Korbi and Chouki, 2017; Simeone, Secundo and Schiuma, 2017). Specifically, partial participation of actions (PEO) can play a strategic role. More specifically, when the focal firm takes a minority equity stake in the innovator (the investee), the relationship is impacted in two main ways: a) Information Flow, helping investors to obtain information concerning the investee; b) Control Over Decisions by the investee (Palmer, 2001; Castro et al., 2007; Hummel, Amiryany, 2015). These two factors affect the quality of the relationship with the investee by better aligning the partners' financial interests as well as discouraging opportunistic behaviors. Moreover, the equity participation creates another point of contact between the two firms, increasing communication channels (Doz, 1998; Jaeyoung, 2014).

\section{References}

Agarwal, R., Audretsch, D., \& Sarkar, M. B. (2010). Knowledge spillovers and strategic entrepreneurship. Strategic Entrepreneurship Journal, 4(4), 271-283.

Agrawal, A. K., Catalini, C., \& Goldfarb, A. (2011). The geography of crowdfunding. National Bureau of Economic Research

Ahlers, G., Cumming, D., Guenther, C., \& Schweizer, D. (2015). Equity crowdfunding. Entrepreneurship Theory and Practice, 39(4), 955-980

Alavi, M., \& Leidner, D. E. (2001). Review: Knowledge management and knowledge management systems: Conceptual foundations and research issues. MIS quarterly, 107-136.

Albino, V., Carbonara, N., Messeni Petruzzelli, A. (2007). Performance of knowledge gatekeepers. Paper presented at the $10^{\text {th }}$ Uddevalla Symposium, Uddevalla, Sweden

Aloini. D., Farina, G., Lazzarotti, V., Pellegrini, L. (2017). Implementing open innovation: conceptual design of an integrated ICT platform. Journal of Knowledge Management, Volume: 21 Issue: 6

Andreeva, T., Kianto, A. (2012). Does knowledge management really matter? Linking knowledge management practices, competitiveness and economic performance. Journal of Knowledge Management, 16 (4), 617636.

Andries, P., \& Czarnitzki, D. (2014). Small firm innovation performance and employee involvement. Small Business Economics, 43(1), 21-38.

Ardichvili, A., Page, W., Wentling, T. (2003). Motivation and barriers to participation in virtual knowledge-sharing communities of practice. Journal of Knowledge Management, Vol. 7 Issue: 1, pp.64-77

Argote, L., \& Ingram, P. (2000). Knowledge transfer: A basis for competitive advantage in firms. Organizational behavior and buman decision processes, 82(1), 150-169.

Argote, L., McEvily, B., \& Reagans, R. (2003). Managing knowledge in organizations: An integrative framework and review of emerging themes. Management Science, 49(4), pp 571-583 
Arora, A., Fosfuri, A., Gambardella, A. (2001). Markets for Technology: Economics of Innovation and Corporate Strategy, Cambridge, MA: MIT Press

Bader, K., \& Enkel, E. (2014). Understanding a firm's choice for openness: strategy as determinant. International Journal of Technology Management 23, 66(2-3), 156-182.

Bao, Z, Huang, T. (2017). External supports in reward-based crowdfunding campaigns: A comparative study focused on cultural and creative projects. Online Information Review, Vol. 41 Issue: 5

Barney, J. (1991). Firm resources and sustained competitive advantage. Journal of management, 17(1), 99120.

Belleflamme, P., \& Lambert, T. (2014). Crowdfunding: Some Empirical Findings and Microeconomic Underpinnings. Revue Bancaire et Financière, 2014 (4), 288-296.

Belleflamme, P., Lambert, T., \& Schwienbacher, A. (2010). Crowdfunding: An industrial organization perspective. Prepared for the Workshop Digital Business Models: Understanding Strategies, Paris, June 2010

Ben Chou, P., Passerini, K., (2009). Intellectual property rights and knowledge sharing across countries. Journal of Knowledge Management, Vol. 13 Issue: 5, pp.331-344

Benner, M., Sandström, U. (2000). Institutionalizing the triple helix: research funding and norms in the academic system. Research Policy, 29,291-301

Bergkvist, L., \& Rossiter, J. R. (2007). The predictive validity of multiple-item versus single-item measures of the same constructs. Journal of Marketing Research, 44(2), 175-184.

Bergkvist, L., \& Rossiter, J. R. (2009). Tailor-made single-item measures of doubly concrete constructs. International Journal of Advertising, 28(4), 607-621.

Bettis, R. A., \& Hitt, M. A. (1995). The new competitive landscape. Strategic management journal, 16(S1), 719.

Bezant, M. (1997). The Use of Intellectual Property as Security for Debt Finance. Journal of Knowledge Management, Vol. 1 Issue: 3

Bican, P.M., Guderian, C.C, Ringbeck, A. (2017). Managing knowledge in open innovation processes: an intellectual property perspective. Journal of Knowledge Management, Vol. 21 Issue: 6

Blau, J. (2006). Microsoft to sell non-core tech. Research-Technology Management, 49(4), 4-5.

Bollinger, A.S., Smith, R.D. (2001). Managing organizational knowledge as a strategic asset. Journal of Knowledge Management, Vol. 5 Issue: 1

Bowman, C., Ambrosini V. (1997). Perceptions of strategic parties, consensus and firm performance. Journal of Management Studies, 34(2): 41-58

Bradford, C. (2012). Crowdfunding and the federal securities laws. Columbia Business Law Review

Brouthers, K., van Hastenburg, P., van den Ven, J. (1998). If Most Mergers Fail Why Are They so Popular? Long Range Planning, 31, pp. 347-353 
Brown, R., Hale, K., Harris, J. (2010). Business Process Outsourcing Worldwide: Forecast Database. Gartner research report

Bruton, G., Khavul, S., Siegel, D., \& Wright, M. (2015). New Financial Alternatives in Seeding Entrepreneurship: Microfinance, Crowdfunding, and Peer-to-Peer Innovations. Entrepreneurship Theory and Practice, 39(1), 9-26

Burkett, E. (2011). A Crowdfunding Exemption? Online Investment Crowdfunding and U.S. Securities Regulation. The Tennessee Journal of Business Law, vol. 13, No. 63.

Burtch, G., Ghose, A., Wattal, S., (2011). An empirical examination of the antecedents and consequences of investment patterns in crowd-funded markets. SSRN Electronic Journal

Busenitz, L., Fiet, J., Moesel, D., (2005). Signaling in venture capitalist-new venture team funding decisions: does it indicate long-term venture outcomes?, Entrepreneurship Theory and Practice 29, 1-12

Carayannis, E.G., Campbell, D.F.J. (2006). Knowledge creation, diffusion, and use in innovation networks and knowledge clusters. A comparative systems approach across the United States, Europe and Asia (pp. 1-25). In: Carayannis, E.G., Campbell, D.F.J. (Eds.), Praeger, Westport

Casimir, G., Ng, Y. N. K., \& Cheng, C. L. P. (2012). Using IT to share knowledge and the TRA. Journal of Knowledge Management, 16(3), 461-479.

Castro Casal, C., Neira Fontela, E. (2007). Transfer of socially complex knowledge in mergers and acquisitions. Journal of Knowledge Management, Vol. 11 Issue: 4, pp.58-71

Chang, S. J., Witteloostuijn, A.V., Eden L. (2010). From the Editors: Common Method Variance in International Business Research. Journal of International Business Studies, 41: 178-184

Chen, Y., Vanhaverbeke, W., \& Du, J. (2015). The interaction between internal R\&D and different types of external knowledge sourcing: an empirical study of Chinese innovative firms. R\&D Management.

Cheng, C. C., \& Shiu, E. C. (2015). The inconvenient truth of the relationship between open innovation activities and innovation performance. Management Decision, 53(3), 625-647.

Chesbrough, H. (2003) Open Innovation: The New Imperative for Creating and Profiting from Technology (Boston: Harvard Business School Press)

Chesbrough, H. (2004). Managing open innovation. Researcb-Technology Management, 47(1), 23-26.

Chesbrough, H. W. (2006). Open innovation: The new imperative for creating and profiting from technology. Harvard Business Press.

Chesbrough, H., \& Crowther, A.K. (2006). Beyond high tech: early adopters of open innovation in other industries. R\&D Management, 36, 229-. [236:]

Chi, L., Holsapple, C.W. (2005). Understanding computer-mediated interorganizational collaboration: a model and framework. Journal of Knowledge Management, Vol. 9 Issue: 1, pp.53-75

Chirico, F., Salvato, C. (2008). Knowledge Integration and Dynamic Organizational Adaptation in Family Firms. Family Business Review, 21:169

Chou, P.B., Passerini, K., (2009). Intellectual property rights and knowledge sharing across countries. Journal of Knowledge Management, Vol. 13 Issue: 5, pp.331-344 
Cohen, S., Kamarch, T., Mermelstein, R. (1983). A global measure of perceived stress. Journal of Health and Social Behavior, 24 (4), 385-396

Cohen, W. M., \& Levinthal, D. A. (1990). Absorptive capacity: A new perspective on learning and innovation. Administrative science quarterly, 128-152

Cohen, W. M., Levinthal, D. A. (1990). Absorptive Capacity: A New Perspective on Learning and Innovation. Administrative Science Quarterly, Vol. 35, No. 1, Special Issue: Technology, Organizations, and Innovation., pp. 128-152

Conyon, M.J., Girma, S., Thompson, S., Wright. P.W. (2002). The impact of mergers and acquisitions on company employment in the United Kingdom. European Economic Review, 46 (1):31-49

Cordova, A., Dolci, J., Gianfrate G. (2015). The Determinants of Crowdfunding Success: Evidence from Technology Projects. Social and Behavioral Sciences, 181

Cruz-González, J., López-Sáez, P., Navas-López, J., E., Delgado-Verde, M. (2014). Directions of external knowledge search: investigating their different impact on firm performance in high-technology industries. Journal of Knowledge Management, Vol. 18 Issue: 5

Cumming, D. J., \& Johan, S. A. (2013). Venture capital and private equity contracting: An international perspective. Academic Press.

Dahlander, L., \& Gann, D. M. (2010). How open is innovation?. Research policy, 39(6), 699-709.

Darroch, J., \& McNaughton, R. (2002). Examining the link between knowledge management practices and types of innovation. Journal of intellectual capital, 3(3), 210-222.

Das, T.K., and Teng, B. (2000). A Resource-based Theory of Strategic Alliances', Journal of Management, 26, pp. 31-61

Datta, D., Puia, G. (1995). Cross-Border Acquisitions: An Examination of the Influence of Relatedness and Cultural Fit on Shareholder Value Creation in US Acquiring Firms. Management International Review, 35, pp. 337-359

Del Giudice, M. (2011). Knowledge and the Family Business. The Governance and Management of Family Firms in the New Knowledge Economy, Springer

Del Giudice, M., \& Maggioni, V. (2014). Managerial practices and operative directions of knowledge management within inter-firm networks: a global view. Journal of Knowledge Management, 18(5), 841-846.

Del Giudice, M., Carayannis, E. G., Maggioni, V. (2016). Global knowledge intensive enterprises and international technology transfer: emerging perspectives from a quadruple helix environment. The Journal of Technology Transfer, 2(42), 229-235.

Del Giudice, M., Straub, D. (2011) IT and entrepreneurism: an on-again, off-again love affair or a marriage? MIS Quarterly, 35, III-VII

Dell'Anno, D., Del Giudice, M. (2015). Absorptive and desorptive capacity of actors within universityindustry relations: does technology transfer matter?. Journal of Innovation and Entrepreneurship 4 (1), 13

Dess, G., Robinson, R. (1984). Measuring Organizational Performance in the Absence of Objective Measures: The Case of the Privately-held Firm and Conglomerate Business Unit. Strategic Management Journal, 5, pp. 265-273 
Donaldson, L. (2001) The Contingency Theory of Organizations, Sage, Thousand Oaks.

Dooley, D. (2001), Social Research Methods, Prentice-Hall, Upper Saddle River, NJ.

Du Chatenier, E., Biemans, H.J.A., Verstegen, J.A.A.M., Mulder, M. (2007). Collaborative knowledge creation in open innovation teams. Eighth International Conference on HRD Research and Practice Across Europe (pp. 27-29)

Dubé, L., Jha, S., Faber, A., Struben, J., London, T., Mohapatra, A., McDermott, J. (2014). Convergent innovation for sustainable economic growth and affordable universal health care: Innovating the way we innovate. Annals of the New York. Academy of Sciences, 1331 (1), 119-141

Dvir, D., Segev, E., \& Shenhar, A. (1993). Technologies varying impact on the success of strategic business units within the Miles and Snow typology. Strategic Management Journal, 14, 155-161.

Edvardsson, I.R., Durst, S. (2014). Outsourcing of knowledge processes: a literature review. Journal of Knowledge Management, Vol. 18 Issue: 4, pp.795-811

Etzkowitz, H., Leydesdorff L. (2000). The dynamics of innovation: from National Systems and "Mode 2" to a Triple Helix of university-industry-government relations. Research Policy 29, 109-123

Fosfuri, A., Tribó, J. A. (2008). Exploring the antecedents of potential absorptive capacity and its impact on innovation performance. Omega, 36 (2), 173-187

Franke, N., Shah, S., (2003). How communities support innovative activities: an exploration of assistance and sharing among end-users. Research Policy 32, 157-178

Freund, R. J., Littell, R.C. (2000). SAS System for Regression (Third edition). Cary, NC: SAS Institute

Gajda, O., \& Mason, N. (2013). Crowdfunding for impact in Europe and the USA. European Crowdfunding Network

Garud, R., \& Nayyar, P.R. (1994). Transformative capacity: continual structuring by intertemporal technology transfer. Strategic Management Journal, 15(5), 365-385

Gelfond, S. H., Foti,A., D. (2012). US\$500 and a click: investing the "crowdfunding" way. Journal of Investment Compliance, 13(4): pp. $9-13$

Gerber, E., Hui, J., \& Kuo, P. (2012). Crowdfunding: Why people are motivated to post and fund projects on crowdfunding platforms. CSCW Workshop

Giudici, G., Nava, R., Rossi Lamastra, C., Verecondo, C. (2012). Crowdfunding: The new frontier for financing entrepreneurship? SSRN Working Paper No. 2157429

Gompers, P., Lerner, J., (2004). The Venture Capital Cycle, MIT Press

Grant, R.M., Baden-Fuller, C. (2004). A Knowledge Accessing Theory of Strategic Alliances. Journal of Management Studies, 41 (1), 61-84

Gugler, K., Siebert R. (2007). Market power versus efficiency effects of mergers and research joint ventures: evidence from the semiconductor industry. Review of Economics and Statistics, 89 (4):645-659 
Hagedoorn, J. (2002). Inter-firm R\&D partnerships: an overview of major trends and patterns since 1960. Research Policy, Vol. 31, pp. 477-492

Hagedoorn, J. (2003). Sharing intellectual property rights - an exploratory study of joint patenting amongst companies. Industrial and Corporate Change, Vol. 12, No. 5

Hansen, M.T., Nohria, N. and Tierney, T. (1999). What's your strategy for managing knowledge? Harvard Business Review, Vol. 77 No. 2, pp. 106-16.

Harison, E., \& Koski, H. (2010). Applying open innovation in business strategies: Evidence from Finnish software firms. Research Policy, 39(3), 351-359.

Hartog, D. N., \& Verburg, R. M. (2004). High performance work systems, organisational culture and firm effectiveness. Human Resource Management Journal, 14(1), 55-78.

Heisig, P. (2009). Harmonisation of knowledge management-comparing $160 \mathrm{KM}$ frameworks around the globe. Journal of knowledge management, 13(4), 4-31.

Hemer, J., Schneider, U., Dornbusch, F., \& Frey, S. (2011). Crowdfunding und andere Formen informeller Mikrofinanzierung in der Projekt und Innovations finanzierung. Stuttgart: Fraunhofer Verlag

Hornuf, L., \& Schwienbacher, A. (2014). Crowdinvesting-Angel Investing for the Masses? Handbook of Research on Venture Capital, 3

Howe, J. (2006). The rise of crowdsourcing. Wired Magazine, 14 (6), 1-4

Hummel, J., T., Amiryany, N. (2015). Determinants of Acquisition Performance: A Multi-Industry Analysis, in Cooper, C., L., Finkelstein, S. (ed.) Advances in Mergers and Acquisitions, Vol. 14

Huo, W., Cai, Z., Luo, J., Men, C., Jia, R. (2016). Antecedents and intervention mechanisms: a multi-level study of R\&D team's knowledge hiding behavior. Journal of Knowledge Management, Vol. 20 Issue: 5, pp.880897

Ingram, C., \& Teigland, R. (2013). Crowdfunding Among IT Entrepreneurs in Sweden: A Qualitative Study of the Funding Ecosystem and ICT Entrepreneurs' Adoption of Crowdfunding. Social Science Research Network, 2289134.

Inkinen, H. (2016). Review of empirical research on knowledge management practices and firm performance. Journal of Knowledge Management, Vol. 20 Issue: 2, pp.230-257

Isenberg, D. (2012). The Road to Crowdfunding Hell. Harvard Business Review

Jacobides, M., \& Billinger, S. (2006). Designing the boundaries of the firm: From "make, buy or ally" to thedynamic benefits of vertical architecture. Organization Science,17: 249-26

Kale, P., \& Singh, H. (2007). Building firm capabilities through learning: The role of the alliance learning process in alliance capability and firm-level alliance success. Strategic Management Journal, 28 (10), 9811000

Kamhawi, E. M. (2012). Knowledge management fishbone: a standard framework of organizational enablers. Journal of Knowledge Management, 16(5), 808-828.

Karabell, Z., (2013). The Kickstarter economy: how technology turns us all into bankers. Atlantic Monthly 
Kenny, D. A., Kashy, D. A., \& Bolger, N. (1998). Data analysis in social psychology. In Gilbert, D., Fiske, S., Lindzey, G. (Eds.), The handbook of social psychology (Vol. 1, 4th ed., pp. 233-265). Boston, MA: McGraw-Hill.

Khedhaouria, A., Jamal, A. (2015). Sourcing knowledge for innovation: knowledge reuse and creation in project teams. Journal of Knowledge Management. Vol. 19 Issue: 5, pp.932-948

Kirschbaum, R. (2005). Open innovation in practice. Research-Technology Management, 48(4), 24-28

Klein, J.T. (2010). The taxonomy of interdisciplinarity. In: Frodeman, R., Klein, J.T., Mitcham, C. (Eds.), Oxford Handbook of Interdisciplinarity, Oxford: Oxford University Press

Korbi, F.B., Chouki, M. (2017). Knowledge transfer in international asymmetric alliances: the key role of translation, artifacts, and proximity. Journal of Knowledge Management, Vol. 21 Issue: 5, pp.1272-1291

Kraemer, W.J., Adams, K., Fleck, S.J. (2002). Progression models in resistance training for healthy adults. Medicine \& Science in Sports \& Exercise, 34,364-380

Krug, J., Hegarty, W. (2001). Predicting who Stays and Leaves After an Acquisition: A Study of Top Managers in Multinational Firms. Strategic Management Journal, 22, pp. 185-196

Krylova, K.O., Vera,D. Crossan M. (2016). Knowledge transfer in knowledge-intensive organizations: the crucial role of improvisation in transferring and protecting knowledge. Journal of Knowledge Management, Vol. 20 Issue: 5, pp.1045-1064

Kühn, O., Abecker, A. (1997). Corporate Memories for Knowledge Management in Industrial Practice: Prospects and Challenges. Journal of Universal Computer Science, 3(8)

Kutner, M. H., Nachtsheim, C. J., Neter J. (2004). Applied Linear Regression Models (4th ed.). McGraw-Hill Irwin.

Lane, P. J., Koka, B. R., Pathak, S. (2006). The reification of absorptive capacity: A critical review and rejuvenation of the construct. Academy of Management Review, 31 (4), 833 -863.

Lavie, D., Stettner U., Tushman M. (2010). Exploration and exploitation within and across organizations. Academy of Management Annals, 4 (1): 109 - 155

Lazear, E. P. (1996). Performance pay and productivity (No. w5672). National bureau of economic research

Le Masson, P., Cogez, P., Felk, Y., \& Weil, B. (2012). Revisiting absorptive capacity with a design perspective. International Journal of Knowledge Management Studies, 5,10-44.

Lehner, O. M., Kaniskas J. (2012). Opportunity Recognition in Social Entrepreneurship: A Thematic Meta Analysis. Journal of Entrepreneurship, 21 (1): 25-58

Lichtenthaler, U. (2009). Outbound open innovation and its effect on firm performance: examining environmental influences. R\&D Management, [39:] 317-330

Lindvall, M., Rus, I., Suman, Sinha S. (2003). Software systems support for knowledge management. Journal of Knowledge Management, Vol. 7 Issue: 5, pp.137-150

Lopez-Nicolas, C., Soto-Acosta, P. (2010). Analyzing ICT adoption and use effects on knowledge creation: An empirical investigation in SMEs. International Journal of Information Management, 30(6), 521-528. 
Lorenzoni, G., \& Lipparini, A. (1999). The leveraging of interfirm relationships as a distinctive organizational capability: a longitudinal study. Strategic Management Journal, 20(4), 317-338

Lubatkin, M. H., Simsek, Z., Ling, Y., \& Veiga, J. F. (2006). Ambidexterity and performance in small-to medium-sized firms: The pivotal role of top management team behavioral integration. Journal of management, 32(5), 646-672.

Luoma, T., Paasi J., Valkokari, K. (2010). Intellectual property in inter-organisational relationships findings from an interview study. International Journal of Innovation Management, 14, 399-414

MacKinnon, J. G. (2000). Computing numerical distribution functions in econometrics. in High Performance Computing Systems and Applications, Pollard, A., Mewhort, D., Weaver, D. (Eds). Amsterdam, Kluwer, 455-470

MacKinnon, J. G., Haug, A. A., Michelis, L. (1999). Numerical distribution functions of likelihood ratio tests for cointegration, Journal of Applied Econometrics, 14, 563-577

Mahoney, T. (1967). Managerial perceptions of organizational effectiveness. Management Science, 14(3), pp. 76-91

Malik, K. (2004). Coordination of technological knowledge flows in firms. Journal of Knowledge Management, Vol. 8 Issue: 2, pp.64-72

March, J. G. (1991). Exploration and exploitation in organizational learning. Organization science, 2(1), 71 87.

Marlett D. (2015). Crowdfunding Art, Science and Technology. A quick survey of the burgeoning new landscape. Leonardo, 48 (1), 104-105

Mata, F. J., Fuerst, W. L., \& Barney, J. B. (1995). Information technology and sustained competitive advantage: A resource-based analysis. MIS Quarterly, 19(4), 487

McConnachie, G. (1997). The Management of Intellectual Assets: Delivering Value to the Business. Journal of Knowledge Management, Vol. 1 Issue: 1, pp.56-62

Meissner, D., Carayannis, E.G. (2017). Value generation from industry-science linkages in light of targeted open innovation. Journal of Knowledge Management, Vol. 21 Issue: 2, pp.295-307

Melville, N., Gurbaxani, V., \& Kraemer, K. (2007). The productivity impact of information technology across competitive regimes: the role of industry concentration and dynamism. Decision Support Systems, 43(1), 229-242.

Melville, N., Kraemer, K., \& Gurbaxani, V. (2004). Review: information technology and organizational performance: an integrative model of IT business value. MIS Quarterly, 28 (2), 283 322.

Merono-Cerdan, A. L., Soto-Acosta, P., \& López-Nicolás, C. (2007). Analyzing collaborative technologies' effect on performance through intranet use orientations. Journal of Enterprise Information Management, 21(1), 39-51

Moenninghoff, S. C., Wieandt, A. (2013). The future of peer-to-peer finance. Schmalenbachs Zeitschriftfür betriebswirtschaftliche Forschung, 65 (5), 466-487

Mollick, E. R. (2013). The Dynamics of Crowdfunding: An Exploratory Study. Journal of Business Venturing, Vol. 29, Issue: 1 
Mortara, L., Napp, J., Ford, S., \& Minshall, T. (2011). Open innovation activities to foster corporate entrepreneurship. In Cassia, L., Minola, T., Paleari, S. (Eds.), Entrepreneurship and Technological Change. Cheltenham, UK: Edward Elgar

Munari, F. and Toschi, L. (2011). Do venture capitalists have a bias against investment in academic spinoffs? Evidence from the micro and nanotechnology sector in the UK. Industrial and Corporate Change, 20(2), pp. 397-432.

Munari, F. and Toschi, L. (2015). Assessing the impact of public venture capital programmes in the United Kingdom: Do regional characteristics matter? Journal of Business Venturing, 30(2), pp. 205-226

Munshi, J. (2014). A Method for Constructing Likert Scales

Muthén, L. K., \& Muthén, B. O. (2002). How to use a Monte Carlo study to decide on sample size and determine power. Structural Equation Modeling, 9(4), 599-620

Nahapiet, J., Ghoshal, S. (1998). Social Capital, intellectual Capital, and the organizational advantage. Academy of management review, Vol.23, no.2, pp. 242-26

Naqshbandi, M. M., \& Naqshbandi, M. M. (2016). Managerial ties and open innovation: examining the role of absorptive capacity. Management Decision, 54(9), 2256-2276.

Natalicchio, A., Ardito, L., Savino, T., Albino, V. (2017). Managing knowledge assets for open innovation: a systematic literature review. Journal of Knowledge Management, Vol. 21 Issue: 6, pp.1362-1383

Nonaka, I. (1994). A dynamic theory of organizational knowledge creation. Organization science, 5(1), 1437.

Oppenheim, A.N. (1992). Questionnaire Design, Interviewing and Attitude Measurement. London, UK: Pinter Publisher

Ordanini,A., Miceli, L., Pizzetti, M., Parasuraman, A. (2011). Crowd-funding: transforming customers into investors through innovative service platforms, Journal of Service Management, Vol. 22 Issue: 4, pp. $443-470$

Overby, E., Bharadwaj, A., \& Sambamurthy, V. (2006). Enterprise agility and the enabling role of information technology. European Journal of Information Systems, 15(2), 120-131

Palacios-Marqués, D., Soto-Acosta, P., \& Merigó, J. M. (2015). Analyzing the effects of technological, organizational and competition factors on Web knowledge exchange in SMEs. Telematics and Informatics, 32(1), 23-32.

Pandza, K., Holt, R. (2007). Absorptive and transformative capacities in nanotechnology innovation systems. Journal of Engineering Technology Management, 24, 347-365

Papa, A., Dezi, L., Gregori, G. L, Mueller, J., Miglietta, N. (2018). Improving innovation performance through knowledge acquisition: the moderating role of employee retention and human resource management practices. Journal of Knowledge Management

Pascucci, F., Cardinali, S., Gigliarano, C., Gregori, G.L. (2017). Internet adoption and usage: evidence from Italian micro enterprises. International Journal of Entrepreneurship And Small Business 
Patrick, H., Sullivan, P.H. (1999). Profiting from intellectual capital. Journal of Knowledge Management, Vol. 3 Issue: 2, pp.132-143

Pavlou, P. A., \& El Sawy, O. A. (2006). From IT competence to competitive advantage in turbulent environments: The case of new product development. Information Systems Research, 17 (3), 198-227

Pénin J, Hussler C, Burger Helmchen T. (2011). New shapes and new stakes: a portrait of open innovation as a promising phenomenon. Journal of Innovation Economics 7, 11-29

Petroni, G., Venturini, K., \& Verbano, C. (2012). Open innovation and new issues in R\&D organization and personnel management. The International Journal of Human Resource Management, 23(1), 147-173

Petruzzelli, A. M. (2014). Balancing knowledge exploration and exploitation within and across technological and geographical domains. Knowledge Management Research \& Practice, 12(2), 123-132.

Piccoli, G., Ives, B. (2005). Review: IT Dependent Strategic Initiatives and Sustained Competitive Advantage: A Review and Synthesis of the Literature. MIS Quarterly 29, (4), 747-776

Pisano, P., Pironti, M., Bertoldi, B. (2009). A Relationship Between Propensity to Innovation and Risk Capital. An Empirical Analysis. Proceedings of the 5th European Conference on IS Management, Leadership and Goverance: ECMLG2009

Plant, R. (2004). Online Communities. Technology in Society, Vol. 26, Issue 1, January 2004, Pages 51-65

Ployhart, R. E., Vandenberg, R.J. (2010). Longitudinal Research: The Theory, Design, and Analysis of Change. Journal of Management, 36 (January 2010): 94-120

Podsakoff, P.M., MacKenzie, S.B., \& Podsakoff, N.P. (2012). Sources of method bias in social science research and recommend actions on how to control it. Annual Review of Psychology, 65, 539-569

Poetz, M., Schreier, M., (2012). The value of crowdsourcing: can users really compete with professionals in generating new product ideas? Journal of Product Innovation Managment 29

Randhawa, K., Josserand, E., Schweitzer, J., Logue, D. (2017). Knowledge collaboration between organizations and online communities: the role of open innovation intermediaries. Journal of Knowledge Management, Volume:21, Issue: 6

Ray, G., Barney, J. B., Muhanna, W. A. (2004). Capabilities, Business, Processes, and Competitive Advantage: Choosing the Dependent Variable in Empirical Tests of the Resource-Based View. Strategic Management Journal, (25), 2004, pp. 23-37

Robert, J. H. (2009). Improving tacit knowledge transfer within SMEs through e-collaboration. Journal of European Industrial Training, Vol. 33 Issue: 3, pp.215-231

Roser, T., De Fillippi, R., Cooke, J. G. (2014). Co-creation in design: how the UK company Own Label combines openness and ownership to manage talent. Strategy \& Leadership, Vol. 42 Issue: 5

Russel, D., Jordan, A., Turnpenny J. (2016). The use of ecosystem services knowledge in policy-making: drawing lessons and adjusting expectations. In: Potschin, M., Haines-Young, R., Fish, R., Turner, R.K. (Eds.), Routledge Handbook of Ecosystem Services, Routledge, London and New York (2016), pp. 586-596

Salmerón Gómez, R., García Pérez, J., López Martín, M. D. M., \& García, C. G. (2016). Collinearity diagnostic applied in ridge estimation through the variance inflation factor. Journal of Applied Statistics, 43(10), 1831-1849 
Sambamurthy, V., Bharadwaj, A., Grover, V. (2003). Shaping Agility through Digital Options: Reconceptualizing the Role of Information Technology in Contemporary Firms. MIS Quarterly, 27(2), 237-263

Sambamurthy, V., Bharadwaj, A., and Grover, V. (2003). Shaping Agility through Digital Options: Reconceptualizing the Role of Information Technology in Contemporary Firms. MIS Quarterly, 27(2), 237-263

Santoro, G., Vrontis, D., Thrassou, A., \& Dezi, L. (2017). The Internet of Things: Building a knowledge management system for open innovation and knowledge management capacity. Technological Forecasting and Social Change.

Santos, F. M., \& Eisenhardt, K. M. (2005). Organizational boundaries and theories of organization.

Schilke, O., Goerzen, A. (2010). Alliance management capability: an investigation of the construct and its measurement. Journal of Management, 36 (5), 1192-1219

Schoenberg R. (2006). Measuring the Performance of Corporate Acquisitions: An Empirical Comparison of Alternative Metrics, British Journal of Management, Volume 17, Issue 4

Schreiner, M., Kale, P., \& Corsten, D. (2009). What really is alliance management capability and how does it impact alliance outcomes and success? Strategic Management Journal, 30 (13), 1395-1419

Schwienbacher, A. (2014). Financing the business. Routledge Companion of Entrepreneurship, 193-206.

Schwienbacher, A., \& Larralde, B. (2010). Crowdfunding of small entrepreneurial ventures. Handbook Of Entrepreneurial Finance, Oxford University Press

Scott, G., \& Chaston, I. (2013). Open innovation in an emerging economy. Management Research Review, 36(10), 1024-1036.

Scuotto, V., Santoro, G., Bresciani, S., Del Giudice, M. (2017). Shifting Intra and Inter Organizational Innovation Processes toward Digital Business. An empirical analysis on SMEs. Creativity and Innovation Management, Vol 26 Issue 3

Secundo, G., Magnier-Watanabe, R., Heisig, P. (2015). Engineering knowledge and information needs in Italy and Japan: bridging the gap between theory and practice. Journal of Knowledge Management, Vol. 19 Issue: 6 , pp.1310-1334

Shadish, W. R., Cook, T. D., \& Campbell, D. T. (2002). Experimental and quasi-experimental designs for generalized causal inference. Boston: Houghton Mifflin.

Shin, S., R., Han, J., Marhold, K., Kang, J. (2017). Reconfiguring the firm's core technological portfolio through open innovation: focusing on technological M\&A. Journal of Knowledge Management, Vol. 21 Issue: 3, pp.571-591

Sideridis, G., Simos, P., Papanicolaou, A., \& Fletcher, J. (2014). Using Structural Equation Modeling to Assess Functional Connectivity in the Brain Power and Sample Size Considerations. Educational and Psychological Measurement

Simeone, L., Secundo,G., Schiuma, G. (2017). Knowledge translation mechanisms in open innovation: the role of design in R\&D projects. Journal of Knowledge Management, Vol. 21 Issue: 6, pp.1406-1429 
Soto-Acosta, P. \& Cegarra-Navarro, J. G. (2016). New ICTs for knowledge management in organizations. Journal of Knowledge Management, 20(3), 417-422.

Soto-Acosta, P., Popa, S., \& Palacios-Marqués, D. (2016). Social web knowledge sharing and innovation performance in knowledge-intensive manufacturing SMEs. The Journal of Technology Transfer, 1-16.

Spender, J. C. (1996). Making knowledge the basis of a dynamic theory of the firm. Strategic management journal, 17(S2), 45-62.

Surowiecki, J. (2005). The wisdom of crowds. New York, Anchor Books. MLA (7th ed.)

Tapscott, D., Williams, A.D. (2007). Wikinomics: How Mass Collaboration Changes Everything. New York: Penguin

Teece, D. J. (1998). Capturing Value from Knowledge Assets: The new economy, markets for knowhow, and intangible assets. California management review, 40(3)

Teece, D. J. (2007). Explicating dynamic capabilities: the nature and microfoundations of (sustainable) enterprise performance. Strategic management journal, 28(13), 1319-1350.

Tippins, M.J., Sohi, R.S. (2003). IT Competency and Firm Performance: Is Organizational Learning A Missing Link? Strategic Management Journal, 24(8), 745-761.

Van de Vrande, V., Lemmens, C., Vanhaverbeke, W. (2006). Choosing governance modes for external technology sourcing. R\&D Management, 36, 347-363

Vanhaverbeke, W. and Cloodt, M. (2006). Open innovation in value networks. In: Chesbrough, H., Vanhaverbeke, W. and West, J. (Eds.): Open Innovation: Researching a New Paradigm, Oxford University Press, Oxford.

Vanhaverbeke, W., Van de Vrande, V. and Chesbrough, H. (2008). Understanding the advantages of open innovation practices in corporate venturing in terms of real options. Creativity and Innovation Management, Vol. 17, No. 4, pp.251-258

Veugelers, R. Cassiman, B. (2005). R\&D Cooperation between Firms and Universities, some empirical evidence from Belgian Manufacturing. International Journal of Industrial Organisation, 23, 5-6, 355-379

Vrontis, D., Thrassou, A., Santoro, G., \& Papa, A. (2016). Ambidexterity, external knowledge and performance in knowledge-intensive firms. The Journal of Technology Transfer, 1-15.

Wang, X., Yujuan, X., Jingsi, X., Zhao, Y. (2017). Organizational unlearning and knowledge transfer in cross-border M\&A: the roles of routine and knowledge compatibility. Journal of Knowledge Management, Vol. 21 Issue: 6, pp.1580-159

West, J., \& Bogers, M. (2014). Leveraging external sources of innovation: a review of research on open innovation. Journal of Product Innovation Management, 31(4), 814-831. 
West, J., \& Lakhani, K. R. (2008). Getting clear about communities in open innovation. Industry and Innovation, 15(2), 223-231.

Wheat, R. E., Wang, Y., Byrnes, J. E., \& Ranganathan, J. (2013). Raising money for scientific research through crowdfunding. Trends in Ecology \& Evolution, 28 (2), 71-72.

Wolf, E. J., Harrington, K. M., Clark, S. L., \& Miller, M. W. (2013). Sample size requirements for structural equation models an evaluation of power, bias, and solution propriety. Educational and Psychological Measurement, 73(6), 913-934.

Wright, M., Lockett, A., Clarysse, B. and Binks, M. (2006). University Spin-out Companies and Venture Capital. Research Policy,35 (4):481-501

Zollo, M. \& Winter, S. G. (2002). Deliberate learning and the evolution of dynamic capabilities. Organization Science, 13: 339-351

Fig 1: Research design

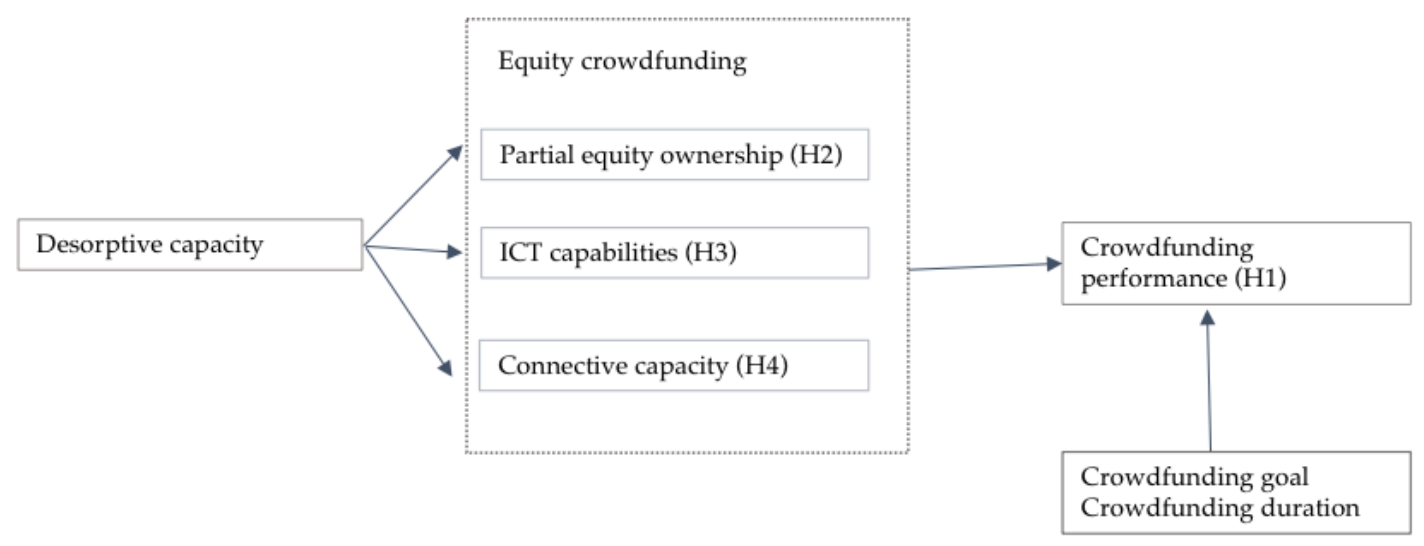


Table 1 Regression model

\begin{tabular}{llll}
\hline Model & Variable & & \\
\hline \multirow{3}{*}{1} & & $B$ & SE \\
& Goal & $-0.04 * * *$ & 0.01 \\
& Duration & $-0.06 \mathrm{~ns}$ & 0.05 \\
& Goal & $-0.07^{* * *}$ & 0.01 \\
& Duration & $-0.05 \mathrm{~ns}$ & 0.05 \\
& Desorptive capacity & $-0.08^{* * *}$ & 0.02 \\
\hline
\end{tabular}

${ }^{* *} \mathrm{p}<0.01$. $^{* * *} \mathrm{p}<0.001$. Ns Not significant

Table 2 Descrriptive Analysis and Correlation

\begin{tabular}{|c|c|c|c|c|c|c|c|c|c|}
\hline & Construct & Mean & $\mathrm{SD}$ & 1 & 2 & 3 & 4 & 5 & 6 \\
\hline 1 & Goal & 2.49 & 0.74 & 1 & & & & & \\
\hline 2 & Duration & 2.13 & 1.04 & $0.22^{* *}$ & 1 & & & & \\
\hline 3 & Desorptive capacity & 5.53 & 0.52 & -0.08 & $0.36^{* *}$ & 1 & & & \\
\hline 4 & Equity acquisition & 5.49 & 0.63 & $0.14^{*}$ & $0.12^{*}$ & $0.23^{* *}$ & 1 & & \\
\hline 5 & ICT capabilities & 5.05 & 1.21 & 0.04 & 0.11 & $0.17 * *$ & $0.28^{* *}$ & 1 & \\
\hline 6 & Connective capacity & 5.58 & 0.83 & 0.11 & 0.11 & $0.15^{*}$ & $0.35^{* *}$ & $0.34 * *$ & 1 \\
\hline 7 & $\begin{array}{l}\text { Crowdfunding } \\
\text { performance }\end{array}$ & 4.89 & 0.86 & $0.35^{* *}$ & 0.05 & $-0.15^{*}$ & $0.12^{*}$ & $0.17 * *$ & $0.34 * *$ \\
\hline
\end{tabular}


Table 3 Regression Analysis

Equity acquisition $\quad$ ICT capabilities $\quad$ Connective capacity

Variable

Model 1 Model 2 Model $3 \quad$ Model $4 \quad$ Model $5 \quad$ Model 6

Controls

$\begin{array}{lcccccc}\text { Goal } & 0.08 & 0.02 & 0.06 & -0.008 & -0.002 & -0.04 \\ \text { Duration } & 0.22^{* *} & 0.12 & 0.14 & 0.10 & 0.17^{* *} & 0.18^{* *} \\ \begin{array}{l}\text { Predictor variable } \\ \text { Desorptive capacity }\end{array} & & & & & \\ \text { Model R2 } & 0.07 & 0.03 & 0.10 & 0.13 & 0.04 & 0.05 \\ \text { Adj R2 } & 0.05 & 0.04 & 0.08 & 0.11 & 0.03 & 0.02 \\ \text { F } & 5.15 & 2.28 & 5.80 & 5.89 & 2.25 & 2.73 \\ * * * \mathrm{p}<.001 ; * * \mathrm{p}<01 . * \mathrm{p}<05, \neq \mathrm{p}<.1 & & & & & \end{array}$

Table 4 Regression Analysis

Dependent Variable equity crowdfunding firm performance

\begin{tabular}{lccccc} 
Variable & Model 7 & Model 8 & Model 9 & Model 10 & Model 11 \\
Controls & & & & & \\
Goal & 0.02 & 0.01 & 0.02 & 0.01 & 0.01 \\
$\begin{array}{l}\text { Duration } \\
\text { Predictor variable }\end{array}$ & $0.32^{* * *}$ & $0.29^{* * *}$ & $0.29^{* * *}$ & $0.30^{* * *}$ & $0.29^{* * *}$ \\
$\begin{array}{l}\text { Desorptive capacity } \\
\text { Equity acquisition }\end{array}$ & & & & & \\
Ict capacity & & 0.10 & 0.07 & 0.09 & 0.07 \\
Connective capacity & & & $0.20^{* *}$ & \\
Model R2 & & & 0.10 & \\
Adj R2 & 0.11 & 0.10 & 0.15 & 0.13 & 0.21 \\
F & 0.08 & 0.08 & 0.14 & 0.11 & 0.19 \\
$* * * \mathrm{p}<.001 ; * * \mathrm{p}<01 . * \mathrm{p}<05$ & 7.82 & 6.80 & 7.28 & 6.90 & 10.84 \\
\hline
\end{tabular}

